\title{
State Service in the Law Enforcement Sphere and Its Major Features ${ }^{1}$
}

\author{
ROMAN V. NAGORNYKH \\ Vologda Institute of Law and Economics of the Federal Penitentiary Service of \\ Russia, Vologda, Russian Federation
}

ORCID: https://orcid.org/0000-0002-4765-8550, e-mail: nagornikhvipe@mail.ru

\begin{abstract}
A bstract. The article investigates the main features of state service in the law enforcement sphere and the place of state service in administrative and legal regulation mechanism. The goals of the work are as follows: to consider state service in the law enforcement sphere as a single legal category, to reveal its essence and characteristic features as a social system, to provide a scientific classification of its constituent elements and disclose their administrative and legal content. We highlight the following main functional features of those state bodies the service in which can be called law enforcement activity: state and power-based nature of activity, exercising executive and administrative powers, special functional and target purpose, application of special measures of legal influence based on the use of persuasion and coercion methods, and a special legal status. We conclude that practical solution to the question of classifying state service in a particular state body as law enforcement activity may be found through legislative definition of the concept of law enforcement activity of the state, law enforcement functions of state authorities, and the system of state authorities exercising law enforcement functions.

Key words: state service; administrative and legal regulation; law enforcement activity; law enforcement functions; legal enforcement.
\end{abstract}

12.00.14. - Administrative law; administrative process.

For c it ation: Nagornykh R.V. State service in the law enforcement sphere and its major features. Penitentiary Science, 2020, vol. 14, no. 4 (52), pp. 576-580. DOI 10.46741/ 2686-9764-2020-14-4-576-580.

Consideration of state service in the law enforcement sphere as a single legal category allows us to reveal its essence and typical features as a social system, to classify its constituent elements from the scientific perspective and to reveal their administrative and legal content. This task can be addressed most effectively by using an integrative approach that identifies and discloses general features of state service in law enforcement and helps understand specific features of its elements and their groups united into separate subsystems, and also helps determine its non-etative features [7], which is of fundamental importance from the point of view of formation of a new model of state service in law enforcement.

In this regard, studying state service as a social and legal system within the law enforcement sphere involves the following aspects:

- studying its functional environment, identifying its interrelations with other social systems (state service system, law enforcement system, state and society, functional environment);

- studying its internal structure and content, components and relationships between them, and their legal regulation;

- identifying major social and humanistic principles of the service and their positivization in current legislation.

On this basis we can give a general description of state service system in the law enforcement sphere as a single social and legal phenomenon [9].

The essence and content of state service in the law enforcement sphere and its social purpose are determined primarily by the external environment of its functioning, which encompasses specific social relations associated with the protection of the interests of individuals, society and the state from various kinds administrative, criminal, natural and man-made threats. At the same time, in the structure of legal order,

\footnotetext{
${ }^{1}$ The paper is based on the materials of the author's Doctor of Sciences (Law) dissertation "Administrative and legal regulation of the state service of the Russian Federation in the law enforcement sphere", it is published for the first time.
} 
that is, in the structure of public relations regulated by law and protected by the state, we can distinguish a group of public relations that have a special social significance and are protected by special legal measures. We are talking about public relations that are protected by the legislation on administrative offenses and criminal legislation. In our opinion, consideration of certain types of public relations as objects of administrative and criminal protection is a fundamental criterion for understanding the content and structure of law enforcement activity and the state law enforcement service as well.

In general, the external functional environment of law enforcement activity can be defined as a set of various social relations regulated by law and protected by special legal measures and means based on legal methods of persuasion and coercion.

The functional environment of law enforcement activity is made up of special groups of public relations that have the highest social value and require special governmental protection; legal protection of these public relations is provides for in special parts of the Code of Administrative Offences of the Russian Federation (RF CAO) and the Criminal Code of the Russian Federation (RF CC). These public relations have specific objects, which are protected within the framework of law enforcement activity in its narrow sense.

Having analyzed Article 1.2 of RF CAO and Article 2 of RF CC that define the objectives of the legislation on administrative offences and the criminal law, we selected a list of objects of legal protection that are a priority for the state and society:

- person (individual and citizen), their rights and freedoms;

- citizens' health;

- sanitary and epidemiological well-being of the population;

- public morals;

- environment;

- established procedure for the exercise of state power;

- public order and public safety;

- property;

- economic interests of natural persons and legal entities, society and the state;

- constitutional system of the Russian Federation;

- peace and security of mankind.

The very necessity to protect these objects implies the use of a wide range of legal prevention measures, measures to promote legal proceedings, bringing to justice, and legal recovery, which, in turn, determine the content of law enforcement activities of the state and their main functions in this field. In accordance with current legislation, these measures serve as specific means for protecting the objects we mentioned above and cannot be used to protect other objects of legal relations. In this regard, the main function of law enforcement activities of the state can be seen in combating crime and administrative offenses, the general aggregate object of which is, in fact, the subject of law enforcement in its narrow sense.

The main law enforcement function of the state can have various sub-types. Thus, according to K.F. Gutsenko and M.A. Kovalev, these sub-types include constitutional control, justice, prosecutor's supervision, detection, investigation and prevention of offenses (crimes), organizational support for the activities of courts, ensuring state and public security, providing legal assistance [3, p. 8]. A viewpoint of V.P. Bozh'ev is in many ways similar: he believes that the law enforcement functions (activities) of the state include constitutional control, administration of justice, prosecutor's supervision, intelligence-gathering activities, investigation of crimes, provision of state security, execution of court decisions, security activity, prevention of crimes and other offenses, provision of professional legal assistance [8, p. 21].

Both viewpoints certainly deserve attention, but they require clarification. In our opinion, the functions that are directly related to the law enforcement activities of state bodies in a broad sense can be as follows: administration of justice, prosecutor's supervision, combating crime (or countering crime), protection of property, protection of public order, ensuring personal, public and state security, execution of decisions on bringing to legal responsibility the judicial and other bodies in the framework of proceedings on criminal cases and administrative offences.

In our opinion, the functions of constitutional control and legal assistance are not directly included in the subject matter of law enforcement in its narrow sense, but are inherent in law enforcement in a broad nation-wide meaning. At the same time, the functions of the administration of justice and prosecutor's supervision have their own specifics due to the presence of special constitutional and legal regulation and the operation of special legislation; thus, they should also be considered outside of law enforcement activity in its narrow sense.

In general, law enforcement activity in the narrow sense should include fight against crime, prevention of offenses, detection and investigation of crimes; protection of public order, 
ensuring personal and public safety, enforcement of decisions of judicial and supervisory authorities. These law enforcement functions are performed by specialized law enforcement agencies of the executive power, which, in turn, also form the corresponding sect oral law enforcement subsystem.

We should note that at present the system of law enforcement agencies of the state (law enforcement system) in the organizational and legal aspect is established most clearly, and its functional and target identification in the system of public administration does not cause noticeable discrepancies. Many researchers, when speaking about the law enforcement system of the state in a narrow sense, mean first of all the judicial authorities, prosecutor's offices and directly law enforcement agencies of the executive power. At the same time, legislative uncertainty of the basic concepts related to law enforcement, its goals, tasks, functions, system, etc. remains a rather long-standing issue. In this regard, we agree with V.M. Isaenko, who substantiates the need for adopting a relevant federal law "On law enforcement activity"' [5, p. 163].

In our opinion, the most accurate classification of state bodies included in the system of law enforcement agencies of the state is given by V.V. Chernikov. He points out that among their constituent elements, along with bodies that have a special constitutional and legal status (the court, the prosecutor's office, and currently the Investigative Committee of the Russian Federation (hereinafter - RF IC)), one should distinguish law enforcement agencies of the executive power, i.e. the system of executive authorities that carry out law enforcement activity in its narrow sense [10, p. 5].

Thus, understanding the system as a set of elements and relationships that are naturally connected to each other in a single whole, whichhas special integrative properties that individual elements and relationships do not possess, we can give the following definition of the law enforcement system of the state. The law enforcement system of the state is a set of state bodies that are duly vested with powers in the field of justice, prosecutor's and investigative activities, and with executive and administrative powers in the field of protecting the rights and interests of citizens from illegal encroachments, fighting crime, protecting public order, ensuring personal and public safety, executing decisions on bringing to legal responsibility through the use of legal measures of persuasion and coercion, as well as other social functions within the framework of administrative, intelligence-gathering, criminal-procedural and criminal-executive activities. A special place in the structure of the law enforcement system of the state belongs to law enforcement agencies of the executive power, which specialize in the implementation of law enforcement activity in its narrow sense.

Law enforcement activity determines not only the content and structure of the law enforcement system of the state, but also the content of the state's law enforcement service. In this regard, based on the analysis of law enforcement functions of the state, we can determine the types of state service in the law enforcement sphere. The initial postulate for such a classification can be the assumption that the system of state law enforcement service is derived from the state's law enforcement activities.

We should point out that currently law enforcement functions are assigned to various state bodies that have different legal status and are not always clearly identified as belonging to a particular branch of government. This problem is particularly evident in relation to the prosecutor's office and investigative bodies (regarding RF IC bodies) that have a special legal status.

In our opinion, as for the definition of the legal status of the prosecutor's office, one should agree with the point of view of A.M. Tarasov, according to which "the prosecutor's office, carrying out public prosecutor's supervision and being a separate and independent state regulatory authority that supervises law enforcement activity, is an independent state authority that is not part of any of the branches of government listed in Article 10 of the Constitution of the Russian Federation" [9, p. 34-38].

Special studies that analyze how the legal status of prosecutor's offices in different countries is determined provide examples which show that they belong to different branches of government [4]. Prosecutor's offices in present-day Russia belong to law enforcement agencies, and the essence of their work brings them close to law enforcement authorities, judging by the range of tasks they address and certain executive and administrative functions they fulfill. However, these bodies have a special constitutional and legal status, which is due to the functions of prosecutor's offices that ensure the rule of law, unity and strengthening of justice, protection of human and civil rights and protected interests of society and government [2, p. 7]. In this regard, at present, the prosecutor's office has developed a special type of state service, which is based on the order of service inherent in the state service. However, this circumstance, due to law enforcement 
specifics, does not exclude the possibility of classifying service in the prosecutor's office as a type of law enforcement service. Here we should pay attention to the fact that criminal investigation as a special law enforcement function of the prosecutor's office, which has until recently been fulfilled by prosecutor's offices, is now transferred to the RF IC [6].

We shall not analyze in detail the status of the prosecutor's office and prospects for the future development of this agency, since these issues form an independent field of modern scientific research. Instead, let us pay attention to the ambiguity and multiplicity of possible ways of their practical resolution. The development of the prosecutor's office in Russia as an independent control and supervisory authority and the body that supports the prosecution in court and protects the rights and freedoms of citizens from unlawful encroachments should include gradual abandonment of its non-core functions, primarily in the sphere of executiveadministrative activity and their gradual transfer to the jurisdiction of the law enforcement agencies of the executive power, such as the Ministry of Justice or the Ministry of Internal Affairs of Russia. While implementing this process, it is quite logical to establish a special federal state authority carrying out powers in the field of criminal justice: such an authority is the Investigative Committee of the Russian Federation, the state service in the IC has its own specifics, which allows us to determine it as state service in the law enforcement sphere.

In this regard, we should dwell on state service in the bodies of the RF IC, which today is essentially identical to the service in the prosecutor's office. At the same time, the bodies of the RF IC perform law enforcement functions in the field of criminal investigation, which are currently carried out by other federal executive authorities (the Ministry of Internal Affairs, the Federal Security Service (FSB) of Russia). In this regard, we consider it advisable to talk about the prospect of identifying RF IC bodies as part of executive authorities. In this case, the service in RF IC bodies should also be classified as a type of state service in the law enforcement sphere of executive authorities. In our opinion, this understanding of the problem makes it possible to solve the most important state task - to establish a unified system of state service in the law enforcement sphere of executive authorities as a special subsystem of state service in the law enforcement sphere.

Thus, classifying RF IC bodies (with subsequent consolidation of all investigative bodies of Russia within this federal state body) as part of executive authorities will make it possible, on the one hand, to resolve the issue of the final formation of a single federal body that performs criminal investigation functions, and on the other hand, to determine the status of state service in the preliminary investigation bodies as a federal state service in the law enforcement sphere of executive authorities.

According to the analysis of the current state of the law enforcement system we identify the following main functional features of state bodies, the service in which can be defined as law enforcement activity:

- state and power-based nature of activity. In the case we are considering, we are talking about state bodies that have powers in the field of law enforcement. These are primarily state bodies that specialize in the implementation of law enforcement function, which is the main focus of their work;

- endowment with executive and administrative powers. In our opinion, among the state bodies that carry out law enforcement activities, a special place belongs to executive authorities. They form the bulk of law enforcement agencies of the state and perform the most significant amount of law enforcement functions. We should note that along with law enforcement bodies of executive authorities there are other bodies that perform state law enforcement functions: bodies of constitutional control, prosecutor's supervision, and justice[1, p. 30], which have a special legal (in some cases, constitutional and legal) status and in which, in our opinion, special types of state service should be provided for;

- special functional and target purpose. Law enforcement agencies, the state service in which is related to the service in the law enforcement sphere, have a special functional purpose. First of all, they perform functions in the field of fighting crime, protecting public order, and ensuring personal and public safety;

- application of special measures of legal influence based on the use of persuasion and coercion methods [11, p. 29; 13]. In fact, this feature is the most important one in revealing the content of law enforcement activities, and it allows us to distinguish law enforcement agencies in the general array of state bodies. In the scientific literature, such legal measures of persuasion and coercion include prevention of offenses, preclusion of offenses, procedural support of proceedings in cases over different offenses, bringing perpetrators to various types of legal responsibility for committed offenses, and restoration of a violated right. In our opinion, the most important feature, according to which a particular state body can be clas- 
sified as a law enforcement body is its being equipped with armament and, accordingly, the empowerment of its employees to apply physical coercion measures to offenders, namely, physical force, special means and weapons;

- special legal status. All bodies with law enforcement functions have a special legal status. First of all, this is reflected in the normative consolidation of the competence to apply legal measures of persuasion and coercion in various areas of law enforcement activity, including administrative, administrative-jurisdictional, intelligence-gathering, criminal procedural, executive (criminal-executive and administrative-executive - executive activity in the field of execution of the decisions of courts and other bodies of administrative jurisdiction on the cases of administrative offenses). The specifics of the legal status of law enforcement agencies determine the administrative and legal status of civil servants, their rights, duties, and responsibilities.

The legal status of state bodies entrusted with law enforcement functions is enacted in the current administrative legislation. At the same time, along with general acts that directly regulate the administrative and legal status of these bodies, their activities are also regulated by a wide range of legislative acts and bylaws in certain types of law enforcement activities, primarily in the areas of administrative, intelligence-gathering, criminal procedural and executive (criminal-executive, administrative-executive) activities.

Thus, the presence of these system-wide (functional-target) features in the work of state bodies is the basis for classifying them as law enforcement agencies and, accordingly, classifying the service in them as a corresponding type of state service in the law enforcement sphere, since such state serviceproceeds from the competence of law enforcement agencies.

Moreover, a practical solution to the question of classifying state service in a particular state body as law enforcement service can be found through legislative definition of the concept of law enforcement activity of the state, law enforcement functions of state authorities and the system of state authorities exercising law enforcement functions.

\section{REFERENCES}

1. Bratko A.G. Pravookhranitel'naya sistema (voprosy teorii): avtoreferat dissertatsii na soiskanie uchenoi stepeni doktora yuridicheskikh nauk [Law enforcement system (theoretical issues): Doctor of Sciences (Law) dissertation abstract]. Moscow, 1992. 41 p.

2. Veliev I.V. Prokuratura v sisteme organov publichnoi vlasti: opyt sravnitel'nogo issledovaniya po materialam Azerbaidzhanskoi Respubliki, Rossiiskoi Federatsii i Respubliki Kazakhstan: avtoreferat dissertatsii na soiskanie uchenoi stepeni doktora yuridicheskikh nauk [The prosecutor's office in the system of public authorities: the experience of a comparative study based on the materials of the Republic of Azerbaijan, the Russian Federation and the Republic of Kazakhstan: Doctor of Sciences (Law) dissertation abstract]. Moscow, 2006. 34 p.

3. Gutsenko K.F., Kovalev M.A. Pravookhranitel'nye organy [Law enforcement agencies]. Moscow: Zertsalo-M, 2010. 496 p.

4. Dodonov V.N., Krutskikh V.E. Prokuratura v Rossii i za rubezhom: sravnitel'noe issledovanie [The prosecutor's office in Russia and abroad: a comparative study]. Moscow, 2001. 192 p.

5. Isaenko V.M. Organization of law enforcement. Aktual'nye problemy rossiiskogo prava = Actual Problems of Russian Law, 2015, no. 9 (58), pp. 162-166. (In Russ.).

6. Federal Law of December 28, 2010 No. 403-FZ "On the Investigative Committee of the Russian Federation". In: Sobranie zakonodatel'stva Rosiiskoi Federatsii [Collection of legislation of the Russian Federation]. 2011. No. 1. Art. 15. (In Russ.).

7. Oboturova N.S. The problem of human rights in the context of the ideas of humanism and transhumanism. Penitentsiarnaya nauka = Penitentiary Science, 2020, vol. 14, pp. 155-161. (In Russ.).

8. Bozh'evV.P., Gavrilov B.Ya. (Eds.). Pravookhranitel'nye organy Rossii: uchebnik dlya vuzov[Law enforcement agencies of Russia: textbook for universities]. Sixth edition, revised and supplemented. Moscow: Izdatel'stvo Yurait, 2019. 296 p.

9. Stelina J. Theoretical concepts of the law of civil servants. Pravoprimenenie = Law Enforcement Review, 2019, vol. 3, no. 2, pp. 21-30. DOI 10.24147/2542-1514.2019.3(2).21-30. (In Russ.).

10. Tarasov A.M. Law enforcement activity: its concept and essence. Rossiiskii sledovatel'=Russian Investigator, 2002, no. 4, pp. 34-38. (In Russ.).

11. Chernikov V.V. Sudebnye, pravookhranitel'nye i kontrol'nye organy Rossii [Judicial, law enforcement and control agencies of Russia]. Moscow: Prospekt, 2002. 686 p.

12. Chislov A.I. Professional'naya pravookhranitel'naya deyatel'nost' (teoretiko-pravovoe issledovanie): avtoreferat dissertatsii na soiskanie uchenoi stepeni doktora yuridicheskikh nauk [Professional law enforcement (theoretical and legal research): Doctor of Sciences (Law) dissertation abstract]. Saint Petersburg, 2000. 48 p.

13. Bocharova N. Administrative justice: comparative and Russian context. BRICS Law Journal, 2016, vol. 3, no. 3, pp. 143-151. DOI 10.21684/2412-2343-2016-3-3-143-151.

\section{INFORMATION ABOUT THE AUTHOR}

ROMAN V. NAGORNYKH - Doctor of Sciences (Law), Associate Professor, Honorary Worker of Higher Professional Education of the Russian Federation, Professor of the Department of Administrative and Legal Disciplines, Vologda Institute of Law and Economics of the Federal Penitentiary Service of Russia, Vologda, Russian Federation. ORCID: https://orcid. org/0000-0002-4765-8550, e-mail: nagornikh-vipe@mail.ru 